\title{
Isolation of Ovicidal Fungi from Fecal Samples of Captive Animals Maintained in a Zoological Park
}

\author{
José A. Hernández ${ }^{1}$, Rosa A. Vázquez-Ruiz ${ }^{2}$, Cristiana F. Cazapal-Monteiro ${ }^{1}$, \\ Esther Valderrábano ${ }^{3}$, Fabián L. Arroyo ${ }^{1}$, Iván Francisco ${ }^{1}$, Silvia Miguélez ${ }^{1}$, \\ Rita Sánchez-Andrade ${ }^{1}$, Adolfo Paz-Silva ${ }^{1}$ and María S. Arias ${ }^{1, *}$ \\ 1 COPAR (Control of Parasites), Animal Pathology Department, Veterinary Faculty, \\ Santiago de Compostela University, Campus Universitario, 27002 Lugo, Spain; \\ joseangelher@gmail.com (J.A.H.); cristianafcm@gmail.com (C.F.C.-M.); \\ leonardoarroba@hotmail.com (F.L.A.); ivanfranciscovazquez@gmail.com (I.F.); \\ silvia.miguelez.r@gmail.com (S.M.); rita.sanchez-andrade@usc.es (R.S.-A.); adolfo.paz@usc.es (A.P.-S.) \\ 2 Department of Botany, Veterinary Faculty, Santiago de Compostela University, Campus Universitario, \\ 27002 Lugo, Spain; rosana.vazquez@usc.es \\ 3 Marcelle Natureza Zoological Park, Outeiro de Rei, 27122 Lugo, Spain; servet.marcellenatureza@gmail.com \\ * Correspondence: mariasol.arias@usc.es; Tel.: +34-982-822126
}

Academic Editor: David S. Perlin

Received: 10 May 2017; Accepted: 31 May 2017; Published: 2 June 2017

\begin{abstract}
There are certain saprophytic fungi in the soil able to develop an antagonistic effect against eggs of parasites. Some of these fungal species are ingested by animals during grazing, and survive in their feces after passing through the digestive tract. To identify and isolate ovicidal fungi in the feces of wild captive animals, a total of 60 fecal samples were taken from different wild animals kept captive in the Marcelle Natureza Zoological Park (Lugo, Spain). After the serial culture of the feces onto Petri dishes with different media, their parasicitide activity was assayed against eggs of trematodes (Calicophoron daubneyi) and ascarids (Parascaris equorum). Seven fungal genera were identified in the feces. Isolates from Fusarium, Lecanicillium, Mucor, Trichoderma, and Verticillium showed an ovicidal effect classified as type 3, because of their ability to adhere to the eggshell, penetrate, and damage permanently the inner embryo. Penicillium and Gliocladium developed a type 1 effect (hyphae attach to the eggshell but morphological damage was not provoked). These results provide very interesting and useful information about fungi susceptible for being used in biological control procedures against parasites.
\end{abstract}

Keywords: ovicidal fungi; zoological park; biological control; sustainability

\section{Introduction}

Adult stages of certain helminths affecting animals release eggs that are passed out in the feces. Once in the soil, different phases are accomplished to attain the infective stage, and the life-cycle is completed when animals feed on pastures [1]. Some of these helminths are zoonotic agents because they can infect humans also [2].

In the soil, there are several possibilities for the transmission of helminths through eggs shed in feces: (1) a larva originates inside the egg in the soil, but the larva does not exit from the egg until it is ingested by the host and excysts at the gut level (nematodes: ascarids, trichurids); (2) the larva originates in the egg, leaves it, and molts in the environment until the infective stage is reached (nematodes: strongylids, ancylostomids), or (3) the larva abandons the egg and infects an intermediate host to reach the infective stage (trematodes, cestodes) [3,4]. In terms of moving capability, parasites 
remain immobile and confined in the eggs until they are ingested (ascarids, trichurids), or leave actively the eggs and scroll in the environment (trematodes; nematodes: strongylids, ancylostomids).

As occurs with domestic species, wild captive animals maintained always in the same paddock (continuous grazing) can be at risk of infection by certain helminths, because they are constantly shedding eggs to the environment. Despite the administration of successful therapy based on anthelmintics, these animals infect again because of the ingestion of infective stages when feeding on grass [5].

Under natural conditions, the presence of some saprophytic fungi in soil that can develop antagonistic effects on the eggs of parasites, with the aim to take nutrients as $\mathrm{C}$ or $\mathrm{N}$, has been reported [6]. The ability of some of these fungi to pass through the gastrointestinal tract of different animal species and survive in their feces has been previously reported, concerning mainly Duddingtonia flagrans, Pochonia chlamydosporia, or Mucor circinelloides [2,7-9]. Hence, their employment has been notably advised in the last decades as a contribution to the control of parasites affecting livestock.

Studies performed on different countries demonstrated the presence of nematophagous fungi in fecal samples from domestic animal species [4,10-17].

Most known species with ovicidal activity are Verticillium spp., Pochonia chlamydosporia, Paecilomyces lilacinus, Trichoderma spp., or Mucor circinelloides [18-20]. By developing the phases of adhesion, colonization, penetration, and deliberation, these fungi develop an ovicidal activity [21,22]. Recently, the role of Trichoderma spp. in the biological control of insects pest such us Xylotrechus arvicola and Acanthoscelides obtectus has been described [23,24]. The objective of this study was to evaluate the presence of fungi with ovicidal activity in the feces of wild animals maintained captive at the "Marcelle Natureza" zoological park (NW Spain).

\section{Material and Methods}

\subsection{Marcelle Natureza Zoological Park}

The current investigation was conducted in "Marcelle Natureza", a 20 ha zoological park located in NW Spain (Outeiro de Rei, Lugo) $\left(43^{\circ} 4^{\prime} 4.71^{\prime \prime}\right.$ N, $7^{\circ} 37^{\prime} 53.50^{\prime \prime}$ W). Collection animals live in fenced semi-free ranging parcels of various sizes. The animals are routinely dewormed in spring and autumn by adding granulated anthelmintic preparations to their diet. Removal of fecal material is performed daily in the paddocks by the keepers, before the visitors arrive.

\subsection{Collection and Analysis of Fecal Samples}

Freshly deposited feces were taken in the morning from a total of 60 paddocks, then put into plastic flasks, and finally brought to the lab. Each fecal sample was analyzed by the flotation test to determine the presence of coccidian cysts/oocysts, eggs of cestodes and nematodes [25]. Briefly, $3 \mathrm{~g}$ of feces were emulsified in $42 \mathrm{~mL}$ of water, stirred shortly, and passed through a $150 \mu \mathrm{m}$ mesh. The filtered solution was collected into two $15 \mathrm{~mL}$ tubes and centrifuged at $2500 \mathrm{rpm}$ for $10 \mathrm{~min}$. The supernatant was discarded and $10 \mathrm{~mL}$ of saturated $\mathrm{NaCl}$ solution $\left(\rho=1.2 \mathrm{~g} / \mathrm{cm}^{3}\right)$ was added to each tube. After $2 \mathrm{~min}$, aliquots of $300 \mu \mathrm{L}$ were taken and observed in a McMaster chamber under a light microscope $(4-10 \times)$ (Leica DM 2500, Barcelona, Spain).

The existence of eggs of trematodes in feces was investigated by means of the sedimentation probe [1]. Five grams of feces were blended with water, filtered through a $150 \mu \mathrm{m}$ sieve, and passed to a $1 \mathrm{~L}$ conic cup. After decanting three times for $15 \mathrm{~min}$, the content was reduced to $50 \mathrm{~mL}$. Finally, aliquots of $300 \mu \mathrm{L}$ were collected to fill a McMaster chamber, and then observed under an optical microscope $(4-10 \times)$ (Leica DM 2500).

\subsection{Isolation of Fungi from the Feces}

By means of the flotation test, captive animals passing eggs of strongyles in their feces were identified. One gram of each fecal sample was placed onto a Petri dish containing water agar with 
chloramphenicol (WA) and incubated at $25^{\circ} \mathrm{C}$ for 15 days [26]. Four replicates were considered for each sample.

Once fungal growth was recorded, fungal isolates were subcultured twice in malt extract agar (MEA; Drogallega, A Coruña, Spain) and corn meal agar (CMA, Sigma, MO, USA) for purification and subsequent identification, following standard protocols [27,28].

Monosporic cultures were obtained on potato glucose agar (PGA, Drogallega) for morphometric and cultural characterization. In some cases, subcultures were made on wheat extract agar with chloramphenicol (AT). Plates were incubated at $18-22{ }^{\circ} \mathrm{C}$ in the dark.

\subsection{Identification of Fungal Species}

The microscopic characterization of the fungal isolates consisted of measurements of 40 conidia, conidiophores, spores/chlamydospores, and sporanges by using an optical microscope (Olympus CX23LEDRFS1, Ashburton, New Zealand) equipped with a digital camera. Measurements were performed with an eyepiece micrometer scale. Identification of the fungal isolates was based on morphological features from pure cultures fungi, by means of keys and species descriptions [29-33].

\subsection{Obtaining Parasites}

Feces of cattle and horses with previous records of infection by parasites were collected and analyzed by using coprological probes. After the observation of eggs of Calicophoron daubneyi (gastric fluke) in bovine feces by using the sedimentation test, eggs were concentrated to $800 \mathrm{eggs} / \mathrm{mL}$.

By applying the flotation probe, eggs of roundworms (Parascaris equorum) were identified in the feces of horses, then purified [21], and finally kept at a concentration of 800 eggs $/ \mathrm{mL}$.

\subsection{Parasiticide Activity Testing Assays}

Two assays were developed by using CMA plates. For each fungus isolated, two sets of plates were prepared; Set 1 received 400 eggs of $C$. daubneyi, and Set 2 received 400 eggs of P. equorum. Ten replicates were carried out for each fungus and parasite.

Ten plates without fungi were provided with 400 eggs of $C$. daubneyi as controls, and the same was done with eggs of P. equorum.

\subsection{Evaluation of the Fungal Parasiticide Activity}

Twenty-two days after placing the parasites, the CMA plates were observed under an optical microscope (Leica DM2500) for recording the changes in the eggs in comparison with their respective controls. Assessment of fungal damage on eggs was carried out according to the following alterations [34]:

- $\quad$ Type 0: Eggs are viable and damage or alterations are not observed.

- $\quad$ Type 1: Hyphae attached to the eggshell but morphological damage was not provoked.

- $\quad$ Type 2: The eggshell and embryo show damage without penetration.

- $\quad$ Type 3: Fungal hyphae enter the egg, grow, and destroy the embryo.

\section{Results}

A total of 13 captive animals passing eggs of strongyles in their feces were detected by means of the flotation test, thus these fecal samples were cultured and subcultured in search of fungal species with activity against parasite eggs.

In all the isolates, a mycelium was developed in the presence of eggs of C. daubneyi and P. equorum, and hyphae attached to the eggshell (type 1 activity) (Figure 1). Isolates identified as Gliocladium (two fecal samples) and Penicillium $(n=3)$ displayed only a type 1 ovicidal effect. The contact area between the hypha of fungi and the egg surface is smooth at the first stage. No damage of superficial structures of eggshell can be observed during this period. During the interaction with the egg, some hyphae of these fungi formed a lentiform penetration organ (appresorium) on the undeveloped egg surface. This 
is considered an important organ involved in the mechanism of penetration of the fungi through the solid eggshell.

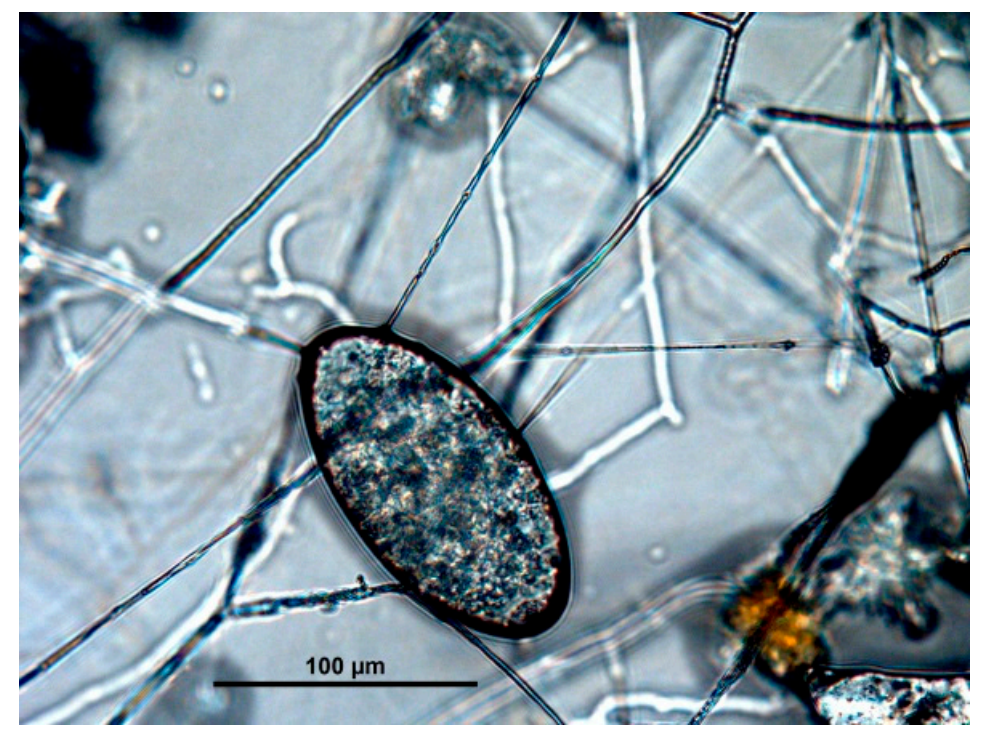

Figure 1. Hyphae of Trichoderma isolated from feces of captive wild animals developed in the presence of eggs of C. daubneyi.

Nine of the fungal isolates were also able to penetrate inside the eggshell after 6-10 days when the penetration organ (haustorium) started to damage the superficial structures of the chitin-protein layer of the envelope. As soon as the fungus has penetrated into the egg, it starts to form branches, and the formation of new hyphae was observed (Figure 2).

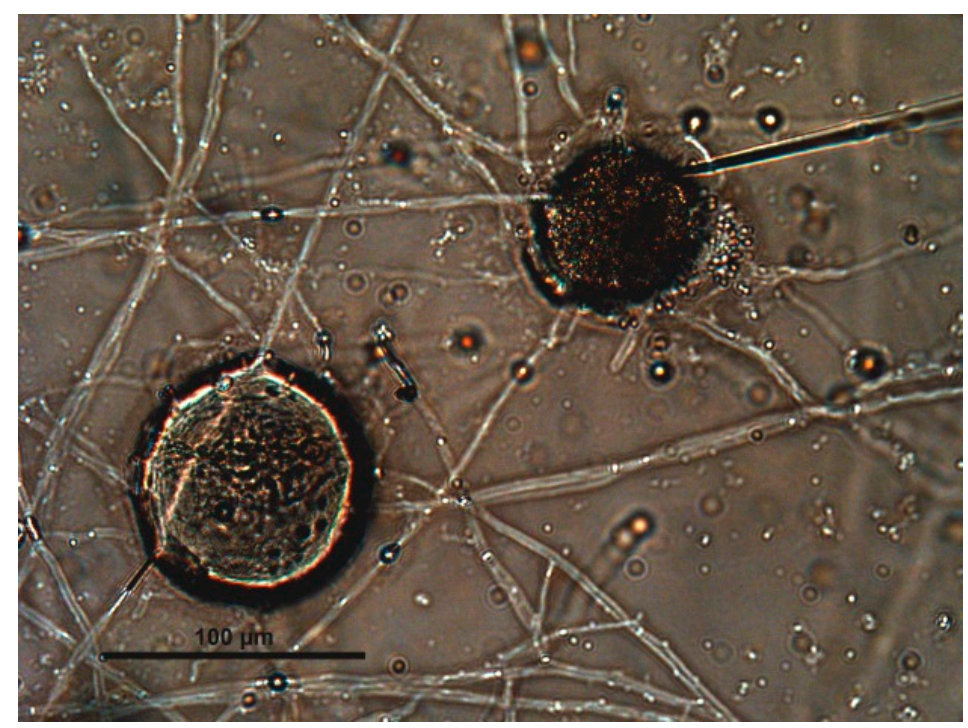

Figure 2. Eggshell of Parascaris equorum is penetrated by hyphae of Mucor spp.

Finally, after attaching to the eggshells and penetrating them, the interior was colonized and, the inner embryo was destroyed (Figures 3 and 4), so this ovicidal activity was classified as type 3 . The consumption stage of the process begins here. The branching fungus starts to gradually liquidate the egg contents irrespective of the developmental stage of the embryo. The layer of the eggshell is already deformed. 


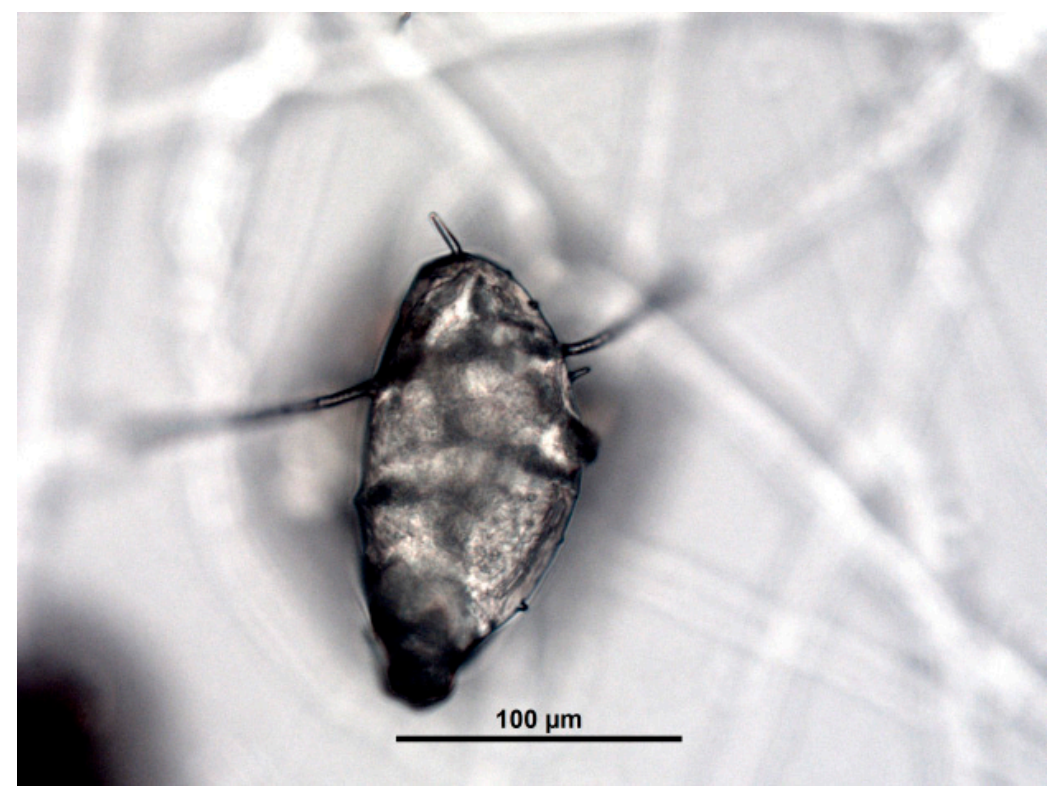

Figure 3. Destruction of the embryo inside egg of $C$. dauneyi by the action of Trichoderma.

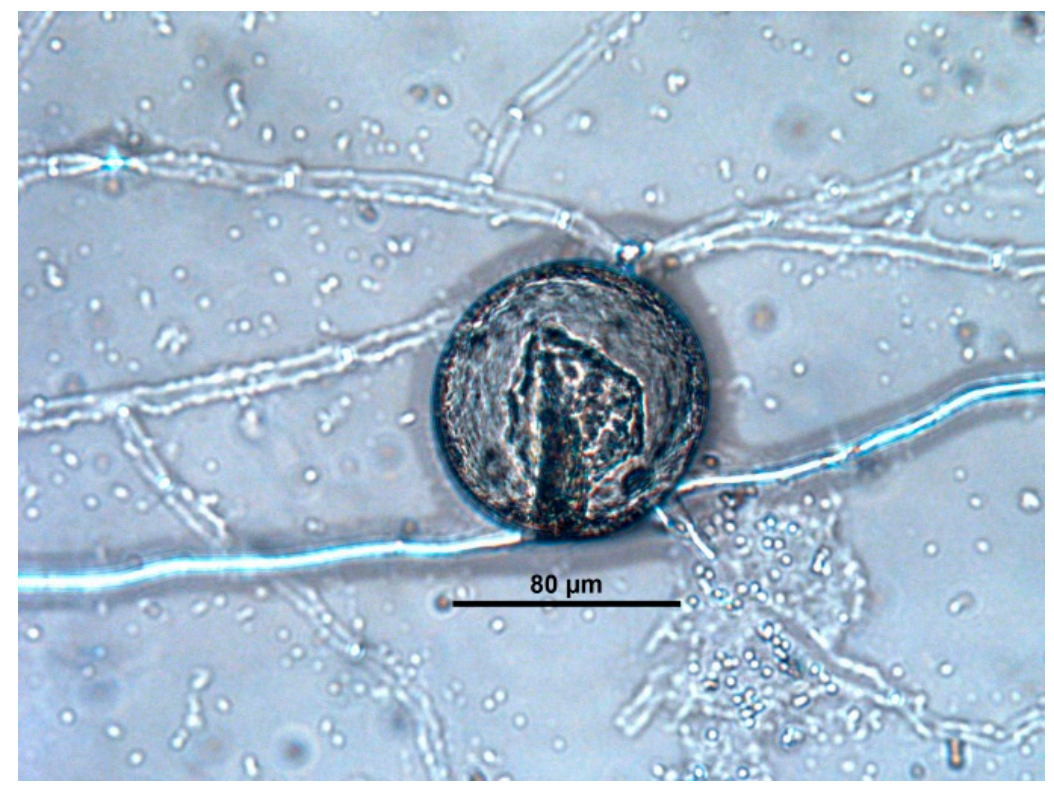

Figure 4. Destruction of the embryo inside egg of P. equorum exposed to Verticillium.

The last stage of the ovicidal process begins, when the ovicidal fungus leaves the liquidated and dead remnants of the nematode egg. In some cases, spores were also observed within the eggs (Figure 5). These isolates were identified as Fusarium, Lecanicillium, Mucor, Trichoderma, and Verticillium.

As summarized in Table 1, the number of fungal species with ovicidal activity in each of the fecal samples ranged between 1 and 2, whereas the most abundant predaceous fungi were, in four samples, Trichoderma and Verticillium, in three samples, Fusarium, Mucor, and Penicillium, Gliocladium in two samples, and Lecanicilium only in one.

No morphological differences regarding the effect the soil fungi developed have been recorded. 
Table 1. Isolation of predaceous fungi with ovicidal activity against eggs of the helminths Calicophoron daubneyi and Parascaris equorum, in feces of wild captive animals (“Marcelle Natureza” zoological park, NW Spain). WA: water agar. MEA: malt extract agar. CMA: corn meal agar. PGA: potato glucose agar. AT: wheat extract agar with chloramphenicol.

\begin{tabular}{|c|c|c|c|c|c|c|}
\hline \multicolumn{3}{|c|}{ Captive Animals } & \multicolumn{4}{|c|}{ Fungal Isolation } \\
\hline Common Name & Scientific Name & Parasites Diagnosed & Culture & Subculture 1 & Subculture 2 & Genera Identified \\
\hline \multirow[b]{2}{*}{ Coati } & \multirow[b]{2}{*}{ Nasua nasua } & \multirow[b]{2}{*}{ Nematodes: Strongyles } & \multirow[b]{2}{*}{ WA } & MEA & & Trichoderma \\
\hline & & & & CMA & & $\begin{array}{l}\text { Trichoderma } \\
\text { Verticillium }\end{array}$ \\
\hline \multirow{2}{*}{ Raccoon } & \multirow{2}{*}{ Procyon lottor } & \multirow{2}{*}{ Nematodes: Strongyles } & \multirow{2}{*}{ WA } & MEA & & Mucor \\
\hline & & & & CMA & & Mucor \\
\hline \multirow{2}{*}{ Eurasian lynx } & \multirow{2}{*}{ Lynx lynx } & \multirow{2}{*}{ Nematodes: Strongyles } & \multirow{2}{*}{ WA } & MEA & \multirow{2}{*}{ PGA } & Fusarium \\
\hline & & & & CMA & & Gliocladium \\
\hline \multirow{2}{*}{ Brown bear } & \multirow{2}{*}{ Ursus arctos } & \multirow{2}{*}{ Nematodes: Strongyles } & \multirow{2}{*}{ WA } & MEA & & Trichoderma \\
\hline & & & & CMA & & Trichoderma \\
\hline \multirow{2}{*}{ Goat } & \multirow{2}{*}{ Capra hircus spp. } & Coccidia & \multirow{2}{*}{ WA } & MEA & \multirow{2}{*}{ PGA } & Verticillium \\
\hline & & Nematodes: Strongyles & & CMA & & Verticillium \\
\hline \multirow[t]{2}{*}{ Mouflon } & \multirow[t]{2}{*}{ Ovis musimon } & Coccidia & \multirow[t]{2}{*}{ WA } & MEA & & $\begin{array}{c}\text { Fusarium } \\
\text { Penicillium }\end{array}$ \\
\hline & & Nematodes: Strongyles & & CMA & & Fusarium \\
\hline \multirow[b]{2}{*}{ Gazelle } & \multirow[b]{2}{*}{ Gazella cuvieri } & Coccidia & \multirow[b]{2}{*}{ WA } & MEA & & Mucor \\
\hline & & Nematodes: Strongyles & & CMA & & $\begin{array}{c}\text { Mucor } \\
\text { Penicillium }\end{array}$ \\
\hline \multirow{2}{*}{ Axis } & \multirow{2}{*}{ Axis axis } & \multirow{2}{*}{ Nematodes: Strongyles } & \multirow{2}{*}{ WA/AT } & MEA & & $\begin{array}{l}\text { Verticillium } \\
\text { Lecanicillium }\end{array}$ \\
\hline & & & & CMA & & $\begin{array}{l}\text { Verticillium } \\
\text { Lecanicillium }\end{array}$ \\
\hline
\end{tabular}


Table 1. Cont

\begin{tabular}{|c|c|c|c|c|c|c|}
\hline \multicolumn{3}{|c|}{ Captive Animals } & \multicolumn{4}{|c|}{ Fungal Isolation } \\
\hline Common Name & Scientific Name & Parasites Diagnosed & Culture & Subculture 1 & Subculture 2 & Genera Identified \\
\hline \multirow{2}{*}{ Bison } & \multirow{2}{*}{ Bison bison } & Coccidia & \multirow{2}{*}{ WA } & MEA & & Trichoderma \\
\hline & & Nematodes: Strongyles & & CMA & & Trichoderma \\
\hline \multirow{2}{*}{ Dromedary } & \multirow[b]{2}{*}{ Camelus dromedarius } & \multirow{2}{*}{ Nematodes: Strongyles } & \multirow[b]{2}{*}{ WA } & MEA & \multirow[b]{2}{*}{ PGA } & Trichoderma \\
\hline & & & & CMA & & $\begin{array}{l}\text { Trichoderma } \\
\text { Verticillium }\end{array}$ \\
\hline \multirow{2}{*}{ Guanaco } & \multirow{2}{*}{ Lama guanicoe } & Coccidia & \multirow{2}{*}{ WA } & MEA & \multirow{2}{*}{ PGA } & Gliocladium \\
\hline & & Nematodes: Strongyles & & CMA & & Gliocladium \\
\hline \multirow[b]{2}{*}{ Falabella } & \multirow[b]{2}{*}{ Equus caballus } & \multirow[b]{2}{*}{ Coccidia } & \multirow[b]{2}{*}{ WA } & MEA & & Fusarium \\
\hline & & & & CMA & & $\begin{array}{l}\text { Fusarium } \\
\text { Penicillium }\end{array}$ \\
\hline \multirow{2}{*}{ Wallaby } & \multirow{2}{*}{ Macropus rufogriseus } & - & \multirow{2}{*}{ WA } & MEA & & Mucor \\
\hline & & & & CMA & & (Sordariaceae) \\
\hline
\end{tabular}




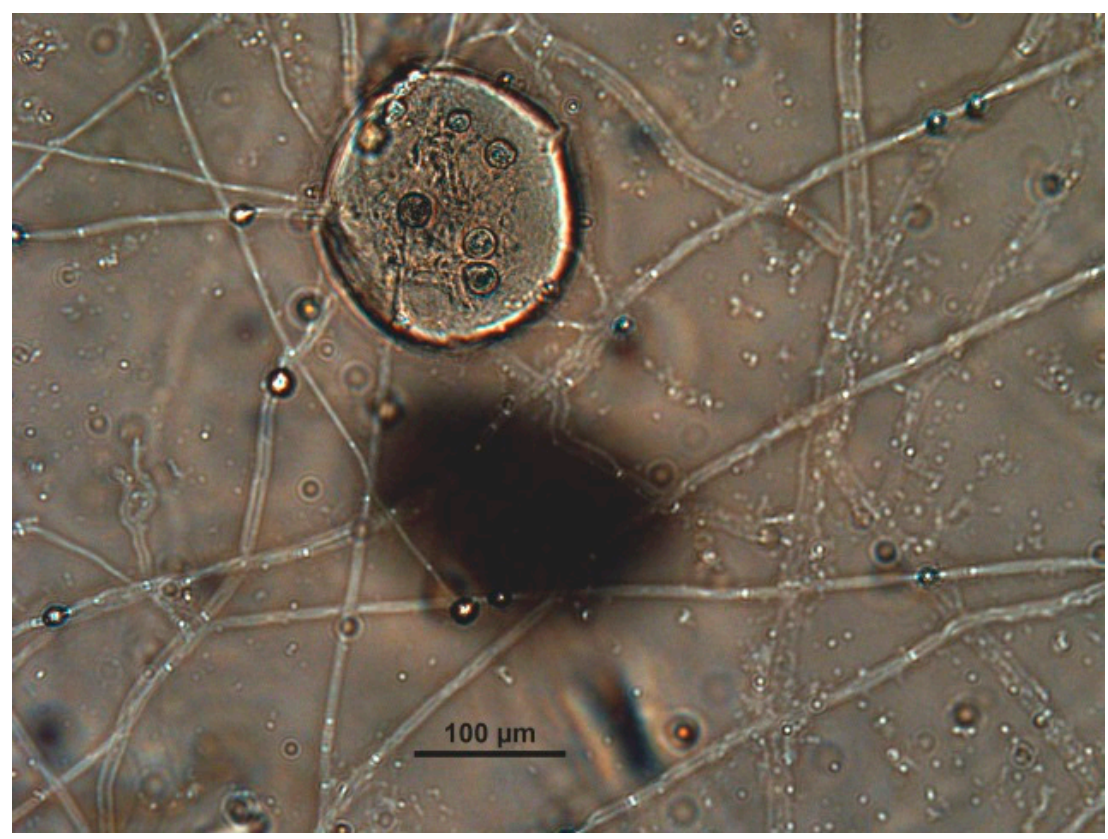

Figure 5. Chlamydospores of Mucor inside of an egg of P. equorum.

\section{Discussion}

The presence of soil fungi antagonists of egg parasites in fecal samples of wild captive animals was investigated. Formerly, only eggs of strongyles were detected in their feces. After culturing these fecal samples, seven isolates with ovicidal activity were obtained. Two of them, identified to genus level as Gliocladium and Penicillium, were able to adhere to eggshell only and therefore classified as type 1 ovicidal fungi. These are specimens found frequently in soil samples [35,36], and there is no available information concerning their effect on the eggs of helminths infecting animals. Some investigations reported their usefulness as a biocontrol agent against plant pathogens as Rhizoctonia solani, Phytium ultimum, and Meloydogine incognita [37-39].

Five fungal specimens isolated from the feces of the captive animals were identified to the genus level as Fusarium, Lecanicillium, Mucor, Trichoderma, and Verticillium. When eggs of the gastric fluke Calicophoron daubneyi and the roundworm Parascaris equorum were exposed to these fungi, it was observed that hyphae attached to the eggshells and penetrated and destroyed the inner embryo, so they were classified as type 3 ovicidal fungi. If the mechanical pressure was the main factor enabling the penetration of the hypha through the eggshell, then the fungi should be fixed to the egg surface in such a way that it would be able to develop a high pressure on the structure of eggshell, particularly on the mechanically resistant chitin-protein complex of the chitinous layer of Ascaris lumbricoides eggs. The penetration organ physically damages the eggshell, though specific enzymes may be involved. The damaged ascarosid layer no longer performs its role of the osmotic barrier. The embryo, if it has not yet been infected by the fungus, can be killed by the injurious substances from the outer environment, which can freely diffuse into the egg [34].

Prior investigations indicated the antagonistic activity of several fungal species belonging to the genera Fusarium and Trichoderma on eggs of the roundworm Toxocara canis [40-42]. The ovicidal activity of Pochonia chlamydosporia (formerly Verticillium chlamydosporium) has been widely reported on eggs of trematodes (Echinostoma paraensei, Fasciola hepatica) and ascarids (T. canis, P. equorum) $[19,20,43]$.

Transmission of many parasites affecting animals occurs in the soil, where the infectious agents develop part of their life-cycle. This enhances the importance to control the numbers of infective stages of parasites, especially when animals are maintained always in the same paddocks, where the continuous shedding of eggs favors the accumulation of infective stages [5]. 
Different actions have been suggested to minimize the risk of infection in grazing animals, such as the rotation of pastures, the alternation of animal species pasturing in the same paddock, the manual collection of manure or drainage [44,45]. Nevertheless, these procedures can not be applied in different regimes, as occurs in zoological parks, and the number of dewormings per year is frequently increased to eliminate parasitic infections in the animals. As a consequence, selection of parasite strains resistant to different chemical compounds [46].

Nematodes in the soil are exposed to many organisms such as bacteria, viruses, fungi, predatory nematodes, and mites, and some have the ability to parasite and destroy them [47]. These beneficial organisms are called biological agents, which should be highly antagonistic to parasites, selective in their activity (acting on parasites but not on crop plants or higher animals), to growth on artificial media at suitable $\mathrm{pH}$ and temperature ranges, and easy to formulate in a working way [48]. In the current research, five of the isolated fungi developed in plates containing a medium composed of corn meal agar and a type 3 effect on eggs of $C$. daubneyi and P. equorum was recorded. No pathogen effects have been reported after the administration of $M$. circinelloides, $D$. flagrans, or Pochonia chlamydosporia to sheep, cattle, and domestic and wild horses $[2,5,7,49,50]$. In recent years, the formulation of fungi in pelleted feed by adding mycelium or spores of $D$. flagrans and $M$. circinelloides provided successful results in terms of preventing infection by helminths in horses, enhancing thus their distribution as biocontrol agents $[2,51]$.

Parasitic stages present in soil can also affect humans. Soil-transmitted helminth infections caused by ascarids, such as Toxocara canis, Ascaris suum, Toxascaris leonina, and Baylisascaris procyonis, and trichurids are transmitted to humans through the accidental ingestion of eggs containing a second stage larva inside [21,42]. Larvae of ancylostomids can penetrate through the skin and especially affect people enjoying recreational locations with, for example, sandy areas or recreational surfaces in parks [52,53]. Parasiticide fungi could be distributed by spraying them into aqueous solutions, providing a useful tool for lessening the risk of infection to children playing in those places or adults taking a sunbath.

Our results demonstrated the existence of saprophytic fungi with ovicidal activity in the feces of captive animals from the "Marcelle Natureza" zoological park (Lugo, NW Spain), and a similar variety of predaceous fungi was observed in all samples examined. Most of the former surveys conducted on fecal samples collected from domestic livestock have been focused on the finding predaceous fungi with larvicidal activity only $[4,13,14,54]$.

In the present investigation, the presence of fungal specimens in feces indicates that they can survive the gastrointestinal tract, and the observation of an ovicidal type 3 effect in five of the isolates demonstrates that fungi retained their biological activity on the eggs of helminths, confirming thus their potential as biological control agents against helminths transmitted through eggs. Their impact on the eggs of strongyle nematodes remains unknown because, according to the weather and/or season, the development of a mobile phase (larva) inside might be slower than the time required for the fungi to develop their ovicidal activity. Further studies are in progress to elucidate this issue.

Acknowledgments: This research was partly supported by the Research Projects AGL2012-34355 and CTM2015-65954-R (Ministerio de Economía y Competitividad, Spain; FEDER). María S. Arias is recipient of a "Parga Pondal" postdoctoral research fellowship (Xunta de Galicia, Spain).

Author Contributions: Rita Sánchez-Andrade, Adolfo Paz-Silva, and María S. Arias conceived and designed the study. Rosa A. Vázquez-Ruiz analyzed the results and wrote the paper. José A. Hernández, Cristiana F. Cazapal-Monteiro, Esther Valderrábano, Fabián L. Arroyo, Iván Francisco, Silvia Miguélez, and María S. Arias performed the experiments.

Conflicts of Interest: The authors declare no conflict of interest. 


\section{References}

1. Sanchís, J.; Sánchez-Andrade, R.; Macchi, M.I.; Piñeiro, P.; Suárez, J.L.; Cazapal-Monteiro, C.; Maldini, G.; Venzal, J.M.; Paz-Silva, A.; Arias, M.S. Infection by Paramphistomidae trematodes in cattle from two agricultural regions in NW Uruguay and NW Spain. Vet. Parasitol. 2013, 191, 165-171. [CrossRef] [PubMed]

2. Braga, F.R.; Araújo, J.V.; Silva, A.R.; Carvalho, R.O.; Araujo, J.M.; Ferreira, S.R.; Carvalho, G.R. Viability of the nematophagous fungus Pochonia chlamydosporia after passage through the gastrointestinal tract of horses. Vet. Parasitol. 2010, 168, 264-268. [CrossRef] [PubMed]

3. Corning, S. Equine cyathostomins: A review of biology, clinical significance and therapy. Parasites Vectors 2009, 2, S1. [CrossRef] [PubMed]

4. Saumell, C.A.; Fernández, A.S. Hongos nematófagos para el control biológico de nematodos parásitos de rumiantes. Rev. Med. Vet. 2000, 81, 270-273.

5. Arias, M.; Cazapal-Monteiro, C.; Valderrábano, E.; Miguélez, S.; Rois, J.L.; López-Arellano, M.E.; Madeira de Carvalho, L.; Mendoza de Gives, P.; Sánchez-Andrade, R.; Paz-Silva, A. A preliminary study of the biological control of strongyles affecting equids in a zoological park. J. Equine Vet. Sci. 2013, 33, 1115-1120. [CrossRef]

6. Barron, G.L. Fungal parasites and predators of rotifers, nematodes, and other invertebrates. In Biodiversity of Fungi: Inventory and Monitoring Methods; Mueller, G.M., Bill, G.F., Foster, M.S., Eds.; Academic Press: New York, NY, USA, 2004; pp. 435-450.

7. Cortiñas, F.J.; Cazapal-Monteiro, C.F.; Hernández, J.A.; Arroyo, F.L.; Miguélez, S.; Suárez, J.; López de Arellano, M.E.; Sánchez-Andrade, R.; Mendoza de Gives, P.; Paz-Silva, A.; et al. Potential use of Mucor circinelloides for the biological control of certain helminths affecting livestock reared in a care farm. Biocontrol Sci. Technol. 2015, 25, 1443-1452. [CrossRef]

8. Mendoza de Gives, P.; Crespo, J.F.; Rodriguez, D.H.; Prats, V.V.; Hernandez, E.L.; Fernandez, G.E.O. Biological control of Haemonchus contortus infective larvae in ovine faeces by administering an oral suspension of Duddingtonia flagrans chlamydospores to sheep. J. Helminthol. 1998, 72, 343-347. [CrossRef] [PubMed]

9. Waller, P.J.; Knox, M.R.; Faedo, M. The potential of nematophagous fungi to control the free-living stages of nematode parasites of sheep: Feeding and block studies with Duddingtonia flagrans. Vet. Parasitol. 2001, 102, 321-330. [CrossRef]

10. Chandrawathani, P.; Jamnah, O.; Waller, P.J.; Hoglund, J.; Larsen, M.; Zahari, W.M. Nematophagous fungi as a biological control agent for nematode parasites of small ruminants in Malaysia: A special emphasis on Duddingtonia flagrans. Vet. Parasitol. 2002, 33, 685-696. [CrossRef] [PubMed]

11. Durand, D.T.; Boshoff, H.M.; Michael, L.M.; Krecek, R.C. Survey of nematophagous fungi in South Africa. Onderstepoort. J. Vet. Res. 2005, 72, 185-187.

12. Ghahfarokhi, S.M.; Abyaneh, M.R.; Bahadori, S.R.; Eslami, A.; Zare, A.; Ebrahimi, M. Screening of soil and sheep samples for predacious fungi: Isolation and characterisation of the nematode-trapping fungus Arthrobotrys oligospora. Iran. Biomed. J. 2004, 8, 135-142.

13. Kelly, P.; Good, B.; Hanrahan, J.P.; Fitzpatrick, R.; de Waal, T. Screening for the presence of nematophagous fungi collected from Irish sheep pastures. Vet. Parasitol. 2009, 165, 345-349. [CrossRef] [PubMed]

14. Larsen, M.; Faedo, M.; Waller, P.J. The potential of nematophagous fungi to control the free-living stages of nematode parasites of sheep: Survey for the presence of fungi in fresh faeces of grazing livestock in Australia. Vet. Parasitol. 1994, 53, 275-281. [CrossRef]

15. Manueli, P.R.; Waller, P.J.; Faedo, M.; Mahommed, F. Biological control of nematode parasites of livestock in Fiji: Screening of fresh dung of small ruminants for the presence of nematophagous fungi. Vet. Parasitol. 1999, 81, 39-45. [CrossRef]

16. McEwen, H. Nematophagous Fungi from Farm Soils in the Lower North Island New Zealand. Master's Thesis, Victoria University of Wellington, Wellington, New Zealand, July 2000.

17. Skipp, R.A.; Yeates, G.W.; Chen, L.Y.; Glare, T.R. Occurrence, morphological characteristic and ribotyping of New Zealand isolate of Duddingtonia flagrans, a candidate for biocontrol of animal parasitic nematodes. N. Z. J. Agric. Res. 2002, 45, 187-196. [CrossRef]

18. Arroyo, F.L.; Arias, M.S.; Cazapal-Monteiro, C.F.; Hernández, J.A.; Suárez, J.; Miguélez, S.; Romasanta, A.; Sánchez-Andrade, R.; Paz-Silva, A. The capability of the fungus Mucor circinelloides to maintain parasiticidal activity after the industrial feed pelleting enhances the possibilities of biological control of livestock parasites. Biol. Control 2016, 92, 38-44. [CrossRef] 
19. De Carvalho, L.M.; Braga, F.R.; Domingues, R.R.; Araujo, J.M.; Lelis, R.T.; de Paula, A.T.; da Silveira, W.F.; de Araújo, J.V. Interaction of the nematophagous fungus Pochonia chlamydosporia and Parascaris equorum eggs in different culture media. J. Basic Microbiol. 2014, 54, S109-S114. [CrossRef] [PubMed]

20. Hiura, E.; del Carmen García Lopes, A.; da Paz, J.S.; Gava, M.G.; Flecher, M.C.; Colares, M.; de Freitas Soares, F.E.; da Fonseca, L.A.; Lacerda, T.; de Araújo, J.V.; et al. Fungi predatory activity on embryonated Toxocara canis eggs inoculated in domestic chickens (Gallus gallus domesticus) and destruction of second stage larvae. Parasitol. Res. 2015, 114, 3301-3308. [CrossRef] [PubMed]

21. Cazapal-Monteiro, C.F.; Hernández, J.A.; Arroyo, F.L.; Miguélez, S.; Romasanta, A.; Paz-Silva, A.; Sánchez-Andrade, R.; Arias, M.S. Analysis of the effect of soil saprophytic fungi on the eggs of Baylisascaris procyonis. Parasitol. Res. 2015, 114, 2443-2450. [CrossRef] [PubMed]

22. Lýsek, H.; Kraícjk, D. Penetration of ovicidal fungus Verticillium chlamydosporium through the Ascaris lumbricoides egg shells. Folia Parasitol. 1987, 34, 57-60.

23. Rodríguez-González, Á.; Frontela, A.; Lorenzana, A.; Henrique da Silva, P.; Mayo, S.; González-López, Ó.; Gutiérrez, S.; Casquero, P.A. Insecticidal activity of Trichoderma harzianum against Xylotrechus arvicola and Acanthoscelides obtectus inmature stages. Planta Med. 2016, 81, S1-S381. [CrossRef]

24. Rodríguez-González, Á.; Mayo, S.; González-López, Ó.; Reinoso, B.; Gutierrez, S.; Casquero, P.A. Inhibitory activity of Beauveria bassiana and Trichoderma spp. on the insect pests Xylotrechus arvicola (Coleoptera: Cerambycidae) and Acanthoscelides obtectus (Coleoptera: Chrisomelidae: Bruchinae). Environ. Monit. Assess. 2017, 189, 12. [CrossRef] [PubMed]

25. Francisco, I.; Arias, M.; Cortiñas, F.J.; Francisco, R.; Mochales, E.; Sánchez, J.A.; Uriarte, J.; Suárez, J.L.; Morrondo, P.; Sánchez-Andrade, R.; et al. Silvopastoralism and autochthonous equine livestock: Analysis of the infection by endoparasites. Vet. Parasitol. 2009, 164, 357-362. [CrossRef] [PubMed]

26. Llerandi-Juárez, J.R.D.; Mendoza de Gives, P. Resistance of nematophagous fungi chlamydospores to the digestive processes of sheep in Mexico. J. Helminthol. 1998, 72, 155-158. [CrossRef]

27. Bills, G.F.; Foster, M.S. Formulae for selected materials used to isolate and study fungi and fungal allies. In Biodiversity of Fungi: Inventory and Monitoring Methods; Mueller, G.M., Bill, G.F., Foster, M.S., Eds.; Academic Press: New York, NY, USA, 2004; pp. 595-618.

28. Davet, P.; Rouxel, F. Détection et Isolement des Champignons du sol; INRA: Paris, France, 1997.

29. Arx, J.A. The Genera of Fungi Sporulating in Pure Culture; Cramer, J.: Vaduz, Liechtenstein, 1974; pp. 1-315.

30. Barnett, H.L.; Hunter, B.B. Illustrated Genera of Imperfect Fungi; MacMilllan Publishing Co.: New York, NY, USA, 1987.

31. Domsch, K.H.; Gams, W.; Anderson, T.H. Compendium of Soil Fungi; Academic Press: London, UK, 1980; Volume 2.

32. Seifert, K.; Morgan-Jones, G.; Gams, W.; Kendrick, B. The Genera of Hyphomycetes; CBS Biodiversity Series; CBS-KNAW Fungal Biodiversity Centre: Utrecht, The Netherlands, 2011; Volume 9, pp. 1-997.

33. Watanabe, T. Pictorial Atlas of Soil and Seed Fungi: Morphologies of Cultured Fungi and Key to Species, 2nd ed.; CRC Press: Boca Raton, FL, USA, 2010.

34. Lýsek, H.; Fassatiová, O.; Cuervo Pineda, N.; Lorenzo Hernández, N. Ovicidal fungi in soils of Cuba. Folia Parasitol. 1982, 29, 265-270. [PubMed]

35. Siddiqui, Z.A.; Mahmood, I. Biological control of Heterodera cajani and Fusarium udum on pigeonpea by Glomus mosseae, Trichoderma harzianum and Verticillium chlamydosporium. Isr. J. Plant Sci. 1996, 44, 49-56. [CrossRef]

36. Vargas Gil, S.; Pastor, S.; March, G.J. Quantitative isolation of biocontrol agents Trichoderma spp., Gliocladium spp. and actinomycetes from soil with culture media. Microbiol. Res. 2009, 164, 196-205. [CrossRef] [PubMed]

37. Lewis, J.A.; Papavizas, G.C. Characterization of alginate pellets formulated with Trichoderma and Gliocladium and their effect on the proliferation of the fungi in soil. Plant Pathol. 1985, 34, 571-577. [CrossRef]

38. Mcquilken, M.P.; Gemmell, J.; Lahdenperä, M.I. Gliocladium catenulatum as a potential biological control agent of damping-off in bedding plants. J. Phytopathol. 2001, 149, 171-178. [CrossRef]

39. Siddiqui, Z.A.; Futai, K. Biocontrol of Meloidogyne incognita on tomato using antagonistic fungi, plant-growth-promoting rhizobacteria and cattle manure. Pest Manag. Sci. 2009, 65, 943-948. [CrossRef] [PubMed] 
40. Bojanich, M.V.; Sarmiento, M.M.; Guisiano, G.; Mangiaterra, M.; Basualdo, J.A. Huevos de Toxocara canis como anzuelo para hongos géofilos en una ciudad subtropical. Rev. Iber. Micol. 2015, 32, 273-276. [CrossRef] [PubMed]

41. Ciarmela, M.L.; Arambarri, A.M.; Basualdo, J.A.; Minvielle, M.C. Effect of saprotrophic soil fungi on Toxocara canis eggs. Malays. J. Microbiol. 2010, 6, 75-80. [CrossRef]

42. De Souza Maia Filho, F.; Nunes Vieira, J.; Aires Berne, M.E.; Stoll, F.E.; Da Silva Nascente, P.; Pötter, L.; Brayer Pereira, D.I. Fungal ovicidal activity on Toxocara canis eggs. Rev. Iber. Micol. 2013, 30, 226-230. [CrossRef] [PubMed]

43. Lelis, R.T.; Braga, F.R.; de Carvalho, L.M.; de Paula, A.T.; Araujo, J.M.; Fausto, M.C.; Junior, A.M.; Rodrigues, J.V.; de Freitas Soares, F.E.; Garcia, J.S.; et al. Effect of the fungus Pochonia chlamydosporia on Echinostoma paraensei (Trematoda: Echinostomatidae). Acta Trop. 2014, 139, 88-92. [CrossRef] [PubMed]

44. Colvin, A.F.; Walkden-Brown, S.W.; Knox, M.R.; Scott, J.M. Intensive rotational grazing assists control of gastrointestinal Nematodirus of sheep in a cool temperate environment with summer-dominant rainfall. Vet. Parasitol. 2008, 153, 108-120. [CrossRef] [PubMed]

45. Fritzen, B.; Rohn, K.; Schnieder, T.; von Samson-Himmelstjerna, G. Endoparasite control management on horse farms-lessons from worm prevalence and questionnaire data. Equine Vet. J. 2010, 42, 79-83. [CrossRef] [PubMed]

46. Geurden, T.; Van Doorn, D.; Claerebout, E.; Kooyman, F.; de Keersmaecker, S.; Vercruysse, J.; Besognet, B.; Vanimisetti, B.; di Regalbono, A.F.; Beraldo, P.; et al. Decreased strongyle egg re-appearance period after treatment with ivermectin and moxidectin in horses in Belgium, Italy and The Netherlands. Vet. Parasitol. 2014, 204, 291-296. [CrossRef] [PubMed]

47. Stirling, G.R. Biological Control of Plant-Parasitic Nematodes; CAB International: Wallingford, UK, 1991.

48. Kim, D.G.; Riggs, R.D. Biological Control; American Phytopathological Society: Washington, DC, USA, 1992; pp. 133-142.

49. Ojeda-Robertos, N.F.; Torres-Acosta, J.F.; Aguilar-Caballero, A.J.; Ayala-Burgos, A.; Cob-Galera, L.A.; Sandoval-Castro, C.A.; Barrientos-Medina, R.C.; de Gives, P.M. Assessing the efficacy of Duddingtonia flagrans chlamydospores per gram of faeces to control Haemonchus contortus larvae. Vet. Parasitol. 2008, 158, 329-335. [CrossRef] [PubMed]

50. Silva, M.E.; Braga, F.R.; Borges, L.A.; Oliveira, J.M.; Lima Wdos, S.; Guimarães, M.P.; Araújo, J.V. Evaluation of the effectiveness of Duddingtonia flagrans and Monacrosporium thaumasium in the biological control of gastrointestinal nematodes in female bovines bred in the semiarid region. Vet. Res. Commun. 2014, 38, 101-106. [CrossRef] [PubMed]

51. Hernández, J.Á.; Arroyo, F.L.; Suárez, J.; Cazapal-Monteiro, C.F.; Romasanta, Á.; López-Arellano, M.E.; Pedreira, J.; de Carvalho, L.M.; Sánchez-Andrade, R.; Arias, M.S.; et al. Feeding horses with industrially manufactured pellets with fungal spores to promote nematode integrated control. Vet. Parasitol. 2016, 229, 37-44. [CrossRef] [PubMed]

52. Criado, P.R.; Belda, W., Jr.; Vasconcellos, C.; Silva, C.S. Cutaneous Larva migrans: A bad souvenir from the vacation. Dermatol. Online. J. 2012, 18, 11. [PubMed]

53. Traub, R.J. Ancylostoma ceylanicum, a re-emerging but neglected parasitic zoonosis. Int. J. Parasitol. 2013, 43, 1009-1015. [CrossRef] [PubMed]

54. Saumell, C.A.; Padilha, T.; Santos, C.; de, P.; Roque, M.VC. Nematophagous fungi in fresh feces of cattle in the Mata region of Minas Gerais state, Brazil. Vet. Parasitol. 1999, 82, 217-220. [CrossRef]

(C) 2017 by the authors. Licensee MDPI, Basel, Switzerland. This article is an open access article distributed under the terms and conditions of the Creative Commons Attribution (CC BY) license (http://creativecommons.org/licenses/by/4.0/). 